\title{
An Integrated Human Resource Information System Framework for Operational Efficiency in Kenya
}

\author{
Benjamin Kimanzi Kyambo ${ }^{1}$, Prof. Stephen Nzuve ${ }^{2}$, Dr. James Njihia ${ }^{3}$ \\ Kisii University and a PhD Candidate with University of Nairobi, P.O.Box 408, Kisii, Kenya ${ }^{1}$ \\ Associate Dean School of Business, University of Nairobi,P.O.Box 30197 GPO Nairobi 00100² \\ Dean School of Business, University of Nairobi, P.O.Box 30197 GPO Nairobi $00100^{3}$
}

\begin{abstract}
The increase in the amount of knowledge that affects organization's ways of doing business has necessitated strategic ways of managing the organizations' resources. The globalization of business is having a significant impact on human resource management practices. An important and fast growing technological innovation is computer- based information systems. Information systems provide an opportunity for businesses to improve their efficiency and effectiveness, and even to gain competitive advantage. One of the information systems in use is the Human Resource Information System. Along with office automation systems capabilities, current Human Resource Information System include features of transaction processing systems, decision support systems, communication systems, and systems with elements of artificial intelligence. Modern Human resource information system should broaden its target and go beyond the organization's borders to address the needs of all stakeholders and help in decision making. This study makes use of the Technology- Organization- Environment Framework because it is used at the firm's level to develop a conceptual framework.
\end{abstract}

Keywords: Human resource management, Human resource information systems, resource based view, TechnologyOrganization- Environment framework

\section{INTRODUCTION}

\section{A. Background of the Study}

NCREASING globalization and competitiveness have brought to the fore the importance of effective human resource Imanagement for national and international organizations. The globalization of business is having a significant impact on human resource management practices; and it has now become imperative for business organizations to engage in human resource management practices on an international standard [13]. As organizations strive to compete in the global economy, differentiation on the basis of the skills, knowledge and motivation of their workforce takes on increasing importance [1]. Resource - Based - View (RBV) proponents view a firm's competitive advantage as based on the strategic accumulation and deployment of unique bundles of resources [15].

Among the first descriptions of alignment in literature is the idea of aligning business with its resources [5] of which one of the most important resource are people working in the organization. Reference [5] suggested that the relationship between organization and its operational performance and efficiency lies on such factors as competitive environment, its structure or its strategy and the appropriate resource alignment. Five types of alignment were identified by [5] as business alignment, IT alignment, environmental alignment or contextual alignment, structural alignment, and strategic alignment. Alignments result from skill rather than luck [5], it is in this context that human resource selection and development is important in any organization. In their conclusion, [5] opined that technology itself may not be a source of competitive advantage because of its ubiquity. The dynamic competency of an organization to align IT strategy with business strategy is a capability that must be developed over time.

The present day domination of natural and financial resources, [11] notes that the world's developed countries are redirecting development goals and strategies towards selection, placement and retention of human resource. Human resources are an organization's greatest assets [14] because without them everyday business could not be completed. Human resources make a key component of strategic information systems for a sustained competitive advantage. With the growing importance of human resource management (HRM) and increasing size and complexity of organizations [37], maintenance of employee related data and generating reports are crucial aspects of the organization. Organizations 
Vol. 8, Issue 4, April 2021

\section{DOI: $10.17148 / I A R J S E T .2021 .8419$}

need information which is accurate, timely and reliable. Reference [37] opined that information systems play an important role in providing information required for crucial decision making which affect directly the performance of an organization. Enterprise applications tend to push organizations towards more centralized and integrated human resource (HR) and information technology (IT) infrastructure [25].

\section{B. Objective of the Study}

The main purpose of this conceptual study paper is to carry out a literature review on the two domains of Human Resource Information System, the human resource and information systems. The main objective of the review is to determine moderating and intervening variables on the relationship between the HRIS implementation and operational efficiency that may be used in proposing an integrated HRIS framework.

\section{LITERATURE REVIEW}

\section{A. The Scope of Human Resource Management}

The subject of the strategic relevance of human resource management in organizational plans and models provides a deep foray into one of the core success factors that effectively underpins the achievement of leadership and managerial objectives [31]. The major HRM activities include HR planning, job analysis, job design, employee hiring, employee and executive remuneration, employee motivation, employee maintenance, industrial relations and prospects of HRM [34]. HRM practices relate to specific practices, formal policies, and philosophies that are designed to attract, develop, motivate, and retain employees who ensure the effective functioning and survival of the organization (Tan et al, 2011). The strategy that management of an organization employs can affect the kind of employees' behavior [13]. HRM is a distinctive approach to employment management which seeks to achieve competitive advantage through the strategic development of a highly committed and capable workforce using an integrated array of cultural, structural and personnel techniques [13].

Modern organizations are more human, offering job security, prosperity, development and education, and advancement of common values respecting their people not only as workers [11], but also as their partners. In order to remain competitive, to grow, and diversify, it is necessary to create new, modern and quality human resources that effectively accomplish the goal of business and development policy [11], an organization must, therefore, ensure that its employees are qualified, placed in appropriate positions, properly trained, managed effectively, and committed to the firm's success. [27] categorized HRM functions as planning, recruitment, selection, appraisal, reward management, development, employee relations, health and safety, union management relation, training, participation, result oriented appraisal and internal career opportunities.

There are three levels at which HRM can be operationalized [13], which are national level (this involves the external labour market, national culture, social-cultural environment, legislations); contingent variables (such as the type and the nature of business, ownership, age among others); organizational strategies (this relates to the HR functions and the internal labour market). For the purpose of this study and in the Kenya context, a fourth level, that is, County level will be included. The territory of Kenya is divided into the counties specified in the First Schedule of the Kenyan constitution. The governments at the national and county levels are distinct and inter-dependent and conduct their mutual relations on the basis of consultation and cooperation [35]; policies and practices are carried out within an economic, social, political and legal environment. Although Kenya has put in place legislations against discrimination on employment, just like in Nigeria [13], there is over reliance on culture, region, language, religion, gender and educational qualifications as a basis for determining who gets employed.

\section{B. IT in Human Resource Management}

In today's competitive environment, one major challenge is effective management of information and a sure way of achieving this is by handling gathered information in an efficient and effective manner using technology [18]. The acceptance of information technologies is part of the need that people have to communicate and for people to communicate they need access points [40]. Access points may take many forms such PCs, the Internet, telephone, fax, mobile phone, television, radio, among others [40]. In order to communicate [40] opined that, people need to master communication skills, learn the technological language, and learn how to use the different instruments for communication. They also advocated that people must have some motivation to communicate. If an organization's communication is to be very open, it is not sufficient for access to new information technology to be easy; it is also necessary for all citizens to have the skills to use the technology and to be motivated to use it to communicate [40]. An important and fast growing technological innovation is computer-based information systems (IS). IS provide an opportunity for businesses to improve their efficiency and effectiveness, and even to gain competitive advantage [36]. One of the information systems in use is the Human Resource Information system (HRIS). HRIS is defined by [32], [10] as a system used to acquire, store, manipulate, analyze, retrieve and distribute pertinent information about an 
Vol. 8, Issue 4, April 2021

\section{DOI: $10.17148 / I A R J S E T .2021 .8419$}

organization's human resources for effectiveness. The multidisciplinary nature of the HRIS field showing an attempt to incorporate IT and HRM domain [32] calls for a look at the relationship between the functionalities of the two domains. HRM has recently turned its concentration on knowledge sharing [27], [34] and strategic workforce analysis. It is evident as HRIS takes hold in the corporate culture that a quality HRIS could provide valuable information to the organization in managing one of its most valuable assets: the organization's human resources [20]. Developments in technology have made it possible to create a real-time information-based, self-service, and interactive work environment. Today's HR technology is moving rapidly to web- based systems to deliver data and services such as employee self-service, online recruiting, web-based training, online applicant testing and online benefits management [16]. [24] outlined seven functions HRIS which are integrated and linked to organizational outcomes through the influence of strategic organizational vision, which drives and integrates the HRIS factors to positive organizational outcomes.

\section{Operational Efficiency}

The objectives of operational efficiency include: aligning resources with core mission and services, reducing fragmented, duplicative operations, focus on effectiveness, efficiency and cost savings, and goal of increasing service levels [12]. Peak operational efficiency occurs when the right combination of people, process and technology come together to optimize organization's performance. Many counties in Kenya face key fiscal challenges: constraints in net revenue growth, increasingly complex regulatory environment, growth in activities that depend on subsidization from the national Government, increasing constituent expectations, and emerging competitive modes of county operations. Devolution in Kenya is a new phenomenon and hence suboptimal practices, systems, and processes have resulted in: frustration, heavy work-loads, ineffective outcomes, and errors, variance in quality of people and local processes supporting tasks, and inadequacy of internal controls. Reference [12] identified seven criteria for success with operational efficiency and corresponding methods for achieving operational efficiency.

\section{Human Resource Information System and Operational Efficiency}

The required organizational approach to the changes in business environment is in formulating strategies that respond to the environment for effective achievement of business goals [17], business strategy and competitive advantage. Reference [17] identified factors that impact strategy implementation as: organizational structure, human resource, leadership, technology and information systems. Effective management of a firm's human resources is a key source of competitive advantage for organizations. Increasingly, the delivery, support and management of HR all depend on technology, specifically, human resource information systems (HRIS). [20] postulates that, HRIS would be more accurately viewed as a hybrid of several classical types of information systems. Along with office automation systems capabilities, current HRIS include features of transaction processing systems, decision support systems, communication systems, and systems with elements of artificial intelligence.

Taking cognizance of the greater involvement HR is playing in the strategic planning process of companies, the need for HRIS is vital [19]. A strategic HRIS provides important information about human resources' needs and capabilities; this information is imperative for management to establish the organizational mission and set and implement goals and objectives [19]. HRIS can support long term HR planning as well as supply and demand forecasts, staffing with information on equal employment [25], [27], applicant qualifications, compensation programs, salary forecast, information on training costs and training work performance. HRIS can also support pay budgets, labor / employee relations with information on contract negotiations and employee assistance needs.

Modern HRIS should broaden its target and go beyond the organization's borders [32] to address the needs of all stakeholders and help in decision making. The increased use of HRIS allow HR professionals to achieve improved performance by freeing the HR members of staff from intermediary roles [20], [25], [32], thus enabling them concentrate on strategic planning through the provision of executive reports and summaries. On the other hand, giving employees access to their information increases the transparency of HR processes [16], and helps employees better understand the role HR plays in the organization. Increasing employees' perception of control over their information can also lead to an increased sense of fairness and job satisfaction.

HRIS can be considered as a tool that provides strategic planners with the needed information enabling them to forecast future workforce demand and supply requirements [33], [27]. HRIS can be considered as a tool that helps employers in retaining the right employees [33] and provide necessary information for planning HRM activities such as forecasting employees demand and supply, compensation system planning, and training and career development of employees. An HRIS should be capable of identifying trends, evaluate and manage costs, compare the organization with other competitive organizations and issue reports [10]. Reference [27] argued that, HRIS has caused a shift from labour intensive HRM to technology intensive HRM and that HRIS should support and integrate various aspects in relation to organizational sustainability based on organizational vision and the strategy of achieving that vision. Reference [24] 
Vol. 8, Issue 4, April 2021

\section{DOI: 10.17148/IARJSET.2021.8419}

identified seven HRIS components (functions) as strategic integration, personnel development, communication and integration, records and compliance, HR analysis, knowledge management, and forecasting and planning.

With use of HRIS, data collected can provide management with a decision-analysis tool rather than just a robust database [20]. Historically, human resource information has largely been seen as a necessary tool in the hiring, administration, and, ultimately, separation of employees [20]. Information technology completely infuses HRM processes and HRM departments in today's global networking timeframe [32]. Introduction of e-HRM into organizational life increasingly calls for an integration of diverse expertise, interdisciplinary comprehension, and modernization of the HR profession [32] and cannot be left to MIS professionals only. Information designers are sometimes constrained by their understanding of key principles, terminology, and issues that are part of information technology [23].

The use of Human Resource Information Systems (HRIS) has been advocated as an opportunity for human resource (HR) professionals to become strategic partners with top management. The idea has been that HRIS would allow for the HR function to become more efficient and to provide better information for decision-making. The question remains whether HRIS has fulfilled its promise [6]. Reference [6] postulated that HRIS will be implemented at three different levels: the publishing of information; the automation of transactions; and, finally, a change in the way human resource management is conducted in the organization by transforming HR into a strategic partner with the line business. HRIS will not only benefit employees and managers, but also suppliers, consultants, benefit providers, and others, as more and more users become connected wirelessly [20]. However, HR departments need to recognize some of the current limitations of web technology and its integration to the HRIS backbone.

Security of private HR information is a top priority [10], since HRIS deals with employees' / prospective employees' personal data which is sensitive. Organizations looking seriously into internet enabling of their HR businesses should evaluate the authentication, security, access rules, and audit trails related to service providers' networks, servers, and applications [4]. Previous research [19] has concentrated on the effectiveness of HRIS in achieving organizational efficiency as having a positive effect on the impact on HR Functions. In their study [4] found out that HR employees perceive HRIS useful and are satisfied with the system. Depending on the sector investigated results show mixed results; [6] concluded that, the directors overall are satisfied with the system, but don't yet see many benefits from its usage outside of its effect on information and information sharing. Part of the problem may stem from the type of organizations that were sampled. Recruiting, hiring, and training probably are handled somewhat differently for public sector employees as compared to employees of private sector organizations, so HRIS in its current form may not yet have had much positive impact in these areas.

Research by [2] indicated that, there was significant statistical effect evidence between the quality of the outcomes of the human resources information systems and the organizational performance in banking sector in Jordan. Organizational structure, culture of the organization and management participation in transforming the organization's operations through the use ICT is vital for sustained competitive advantage. A study by [39] on the Influence of Management Participation on Adoption of HRIS in the Teachers' Service Commission (TSC) Operations in Kenya concluded that, management participation has significant influence on adoption of HRIS. Disparate researches on the impact and usage of HRIS concentrates on the pure administrative use of HRIS and its strategic use [6]. Ultimately the goal of both is to increase organizational value. There is lack of easily accessible workforce databases to conduct complex modeling activities ([26] in Kenya. This makes it difficult for counties in Kenya to be able to attract qualified personnel from within and without the counties. The matter is aggravated by the fact that most counties use their websites or print and electronic media to advertise for vacancies that exist in which potential applicants may not have access to.

\section{THEORITICAL ANCHORAGE OF THE STUDY}

The functional parallels between IS adoption and technological innovation adoption have been suggested by various IS researchers [36]. Since IS can be considered as a technological innovation, it may be fruitful to use technological innovation theories as a reference discipline for empirical studies of IS adoption. Davis's Technology Acceptance Model (TAM) used the Theory of Reasoned Action and Theory of Planned Behavior to explain why some IS are more readily accepted by users than others [29]. Fears about economic conditions and increasing competition create pressures to cut costs, which require organizations to measure and examine the benefits and costs of technology. Naturally, organizations are interested in knowing the return on these investments. The impacts of IT are often indirect and influenced by human, organizational, and environmental factors; therefore, measurement of information systems (IS) success is both complex and illusive [29].

\section{A. The Resource-Based View of the Firm}

The resource-based view argues that firms possess resources, a subset of which enables them to achieve competitive advantage, and a further subset which leads to superior long-term performance [29]. Resources that are valuable and 
Vol. 8, Issue 4, April 2021

\section{DOI: $10.17148 / I A R J S E T .2021 .8419$}

rare and whose benefits can be appropriated by the owning (or controlling) firm [29] provide it with a temporary competitive advantage. That advantage can be sustained over longer time periods to the extent that the firm is able to protect against resource imitation, transfer, or substitution. One of the key challenges RBV theorists have faced is to define what is meant by a resource. Reference [15] opined that, unlike office furniture and computers, employees are often free to negotiate their terms of employment with the employer, and free to leave and join competing organizations if they choose. This makes it challenging to describe human beings as a resource. However, some researchers, [15], opined that, employees are viewed as a capital resource that requires investment ...people are perhaps the only sustainable source of competitive advantage ...when human capital investments are successful ...continuous learning and leveraging the firm's expanding knowledge base are linked with strategic success. Viewing employees as a resource to be maximized rather than a cost to be minimized facilitates the successful implementation of a firm's strategies.

In order to simplify the interpretation of the RBV theory, [38] define resources as assets and capabilities that are available and useful in detecting and responding to market opportunities or threats. Together, assets and capabilities define the set of resources available to the firm. Capabilities can include skills, such as technical or managerial ability, or processes, such as systems development or integration [38].RBV theory provides a valuable way for IS researchers to think about how information systems relate to firm strategy and performance. In particular, the theory provides a logical framework to evaluate the strategic value of information systems resources. It also provides guidance on how to differentiate among various types of information systems; including the important distinction between information technology and information systems; and how to study their separate influences on performance [38]. Further, the theory provides a basis for comparison between IS and non-IS resources, and thus can facilitate cross-functional research [38]. Reference [38] argue that information systems resources are necessary, but not sufficient, for sustained competitive advantage. Information systems exert their influence on the firm through complementary relationships with other firm assets and capabilities.

\section{The DeLone \& McLean IS Success Models}

Fears about economic conditions and increasing competition create pressures to cut costs, which require organizations to measure and examine the benefits and costs of technology [29]. The evaluation of IS practice, policies, and procedures requires an IS success measure against which various strategies can be tested. Without a well-defined dependent variable, much of IS research is purely speculative [9]. The D\&M IS Success Model, though published in 1992, was based on theoretical and empirical IS research conducted by a number of researchers in the 1970s and 1980s [8]. In 1992, DeLone and McLean developed an IS success model. The IS success model, consisting of six interdependent constructs (system quality, information quality, use, user satisfaction, individual impact, and organizational impact, implies that a measurement instrument of "overall success," based on items arbitrarily selected from the six IS success categories, is likely to be problematic [9]. These six variables are not independent success measures, but are interdependent variables [29], [8].

Researchers should systematically combine individual measures from the IS success categories to create a comprehensive measurement instrument posits [9]. As the impacts of IS have evolved beyond the immediate user, additional IS impact measures, such as work group impacts, inter-organizational and industry impacts, consumer impacts, and societal impacts [8] are necessary. Rather than complicate the model with more success measures, the D \& M model was modified to group all the impact measures into a single impact or benefit category called net benefits [8] and added a third dimension, service quality ,to the two original system characteristics, systems quality and information quality. The updated D\&M IS Success Model includes arrows to demonstrate proposed associations among success dimensions in a process sense, but does not show positive or negative signs for those associations in a causal sense [8]. The updated D\&M model has been found to be a useful framework for organizing IS success measurements [29]. Each of the variables describing success of an information system was consistent with one or more of the six major success dimensions of the updated model.

\section{The Technology-Organization-Environment Framework}

The technology-organization-environment (TOE) framework was introduced by Tornatzky and Fleischer in 1990 [3] and uses three elements that influence technological adoption: the environmental context, the organization context, and the technological context. [22] opined that, the technological context considers the available technologies important to the firm, both internal and external, that might be useful in improving organizational productivity, and the organizational context is defined in terms of resources available to support the acceptance of the innovation. These criteria include firm size and scope; the centralization, formalization, interconnectedness, and complexity of the managerial structure [28]; and the quality and availability of the firm's human resources. The environmental context represents the setting in which the firm conducts business, and influenced by the industry itself, its competitors, the firm's ability to access resources supplied by others, and interactions with the government [3], [28]. 
Vol. 8, Issue 4, April 2021

DOI: $10.17148 /$ IARJSET.2021.8419

\section{RESEARCH GAPS AND CONCEPTUAL FRAMEWORK}

There are conflicting interpretations and levels of application of e-HRM by diverse stakeholders [32]. Review of various studies on HRIS and e-HRM on the impact of HRIS [19], [30], [32], [21] indicate that appropriate utilization of HRIS could influence the performance of an organization positively. These studies failed to implore whether there is any attempt by HR professional to take cognizant of technology and organizational structure in depth. Although an HRIS should be capable of identifying trends and compare the organization with other competitive organizations and issue reports [10], relationship between human resource management practices and IS adoption on an organizational performance has not been explored.

According to [39], the full use of ICT provides new avenues for resolving the problems of information asymmetry and information poverty that characterize rural areas in Africa. ICT enabled farmers to receive real time information on input product prices, weather conditions, pest infestation and related farm management extension advice [39]. This is an indication that with well managed and elaborate HRIS, it is possible to disseminate employment opportunities to qualified would be employees in remote areas in Kenya. This paper, therefore, intends to establish the relationship between HRIS implementation and operational efficiency and joint effect of HRM practices and external task environment on the relationship between HRIS implementation and operational efficiency.

\section{A. Conceptual Framework}

The literature reviewed indicates that there are several variables that affect the relationship between human resource information system implementation and operational efficiency. The conceptual framework shown at Figure 5.1 schematically displays the expected relationships between the different variables.

\section{B. Hypotheses}

A hypothesis is a supposition or proposed explanation made on the basis of limited evidence as a starting point for further investigation. This study proposes four hypotheses as follows:

H1: Human resource information system implementation has a significant effect operational efficiency.

H2: Human resource management practices have a significant effect on the relationship between human resource information system implementation and operational efficiency.

H3: External environment task factors have a significant effect on the relationship between human resource information system implementation and operational efficiency.

H4: The joint effect of external task environment factors and human resource management practices is significantly higher than the sum total of individual factors.

\section{The Dependent Variable}

The dependent variable is the variable of primary interest to the researcher and the goal is to be able to understand, describe explain or predict how the variable will behave. In the conceptual framework (Figure 5.1), operational efficiency is of primary interest and it would be of value to investigate how HRIS implementation affects operational efficiency. In this paper, it is suggested that the relationship between HRIS implementation and operational efficiency should be established.

\section{The Independent Variable}

In the conceptual framework (Figure 5.1), HRIS is taken as the independent variable since it may cause or influence operational efficiency to change. The influence of the independent variable over the dependent variable could be either positive or negative. The effectiveness of HRIS in achieving organizational efficiency has a positive effect according to [19].

\section{E. The Moderating Variable}

External task environment (Organizational characteristics, Technology support infrastructure government regulations and organizational competitors) can have a strong contingent effect on the relationship between HRIS implementation and operational efficiency. The external task environment characteristics can have a bearing on the strength of the relationship between HRIS implementation and operational efficiency.

\section{F. The Intervening Variable}

In the conceptual framework (Figure 5.1), HRM practices may have an influence after the relationship between HRIS implementation and operational efficiency has been established. HRM practices (Employee selection, Compensation, Employment security, Training) may remain unnoticed on the effect of the relationship between HRIS implementation and operational efficiency. 


\section{DOI: $10.17148 / I A R J S E T .2021 .8419$}

\section{IMPLICATION OF THE STUDY ON POLICY THEORY AND PRACTICE}

Extant research regarding the usage and impact of HRIS on HRM indicates that there is increased interest in HRIS functions that yield increased organizational performance. e-HRM is believed to facilitate global talent search and retention [32], but for application to be useful, stakeholders need to acknowledge the usefulness. This study would contribute to debate of the antecedents that contribute to an organization's performance. Put into practice, the findings would help practitioners and researchers to investigate whether external task environment and human resource practices jointly impact on the operational efficiency of an organization.

As noted in the objective of this study, this is an ongoing PhD thesis work and hence findings and discussions are not available at the moment.

\section{REFERENCES}

[1] Aguinis, H., \& Kraiger, K.(2009). Benefits of training and development for individuals and teams,organizations, and society. The Annual Review of Psychology, 60(4), 51-74

doi: 10.1146/annurev.psych.60.110707.163505

[2] Al-Tarawneh, M., \& Tarawneh, H. (2012). The effect of applying human resources information system in corporate performance in the banking sector in Jordanian firms. Intelligent Information Management, 4(02), 32-38. http://dx.doi.org/10.4236/iim.2012.42005

[3] Angeles, R. (2014). Using the technology-organization-environment framework for analyzing Nike's "Considered Index" green initiative, a decision support system - driven system. Journal of Management and Sustainability. 4(1), 96-113. doi:10.5539/jms.v4n1p96

[4] Bal, Y., Bozkurt, S., \& Ertemsir, E. (2013). The importance of using human resources information systems (HRIS) and a research on determining the success of HRIS. Strategic Human Resource Management at Tertiary Level, 19(1), 53-62.

[5] Baker, J., Cao, Q,. Jones, D., \& Song, J. (2009). Dynamic strategic alignment competency: A theoretical framework and an operationalization, proceedings of JAIS theory development workshop. Sprouts:Working Papers on Information Systems, 9(48).http://sprouts.aisnet.org/9-48

[6] Beadles, N., Lowery, C. M., \& Johns, K. (2005). The impact of human resource information systems. An explanatory study in the public sector. Communication of the IIMA, 5(4), 39-46.

[7] Chen, S., Li, S., \& Li, C. (2011). Recent related research in technology acceptance model: a literature review. Australian Journal of Business and Management Research, 1(9), 124-127.

[8] DeLone, W. H., \& McLean, E. (2003). The DeLone and McLean model of information systems success: A ten - year update. Journal of Management information Systems, 19(4), 9-30. Available at http://www.jstor.org/stable/40398604.

[9] DeLone, W. H., \& McLean, E. (1992). Information systems success: The quest for the dependent variable. Information Systems Research, 3(1), 60-95. Available at http://www.jstor.org/stable/23010781.

[10] Deshpande, M., \& Nagendra, A. (2014). Human resource information systems (HRIS) in HR planning and development in mid to large sized organizations. Procedia - Social and Behavioral Science 133(2014), 61-67. doi:10.1016/j.sbspro.2014.04.169

[11] Durkovic, J.V. (2009), Development of human resources strategic factors of the companies' competitive advantage. Economics and Organization, 6(1), 59-67

[12] Dracos, W., Huston,P., Fellouris, M,. \& Patil, M. (2012). Model for operational efficiency and practice improvement. NACUBO Internal Presentations. http://carolinacounts.unc.edu/assets/files/NACUBO_InternalPresentation_v13_061112.pdf

[13] Fajana, S., Owoyemi, O., Elegbede, T., \& Sherriff, M. G. (2011). Human resource practices in Nigeria. Journal of Management and Strategy, 2(2), 57-62. doi: 10.5430/jms.v2n2p57

[14] Haslinda, A. (2009). Evolving terms of human resource management and development. The Journal of International Social Research, 2(9), 180-186

[15] Inkson, K. (2008). Are humans resources? Career Development International, 13(3), 270-279.

http://dx.doi.org/10.1108/13620430810870511

[16] Johnson, R.D., \& Gueutal, H.G. (2014). Leveraging HR technology for competitive advantage. SHRM Foundation Executive Briefing.

http://www.shrm.org/about/foundation/products/documents/hris\%20exec\%20briefing\%20final.pdf

[17] Khan, J, N., Azhar, S., \& Hayat, Z. (2014). Staregic approach to job design: An issue in strategic implementation. International Journal of Human Resource Studies, 5(1), 48-68

http://dx.doi.org/10.5296/ijhrs.v5il.6794

[18] Kiptoo, T., S., Kyambo, B., \& Awuor , F., M. (2014). Adoption of MIS in middle level training institutions in Kenya. Computer Science and Information Technology, 2(3), 133-141.

doi: $10.13189 /$ csit.2014.020303

[19] Kumar, N. A., \& Parumasur, S.B. (2013). Management perceptions of the impact of HRIS on organizational efficiency. Journal of Economic and Behavioral Studies, 5(12), 861-875)

[20] Kovach, A.K., Hughes, A.A., Fagan, P., \& Maggitti,P.G.(2002). Administrative and strategic advantages of HRIS. Employment Relations Today, 29(2), 43-48. doi: 10.1002/ert/0039

[21] Lennick-Hall, M. L., \& Moritz, S. (2003). The impact of e-HR on the human resource function.

Journal of Labor Research, 24(3), 365-379

[22] Lippert, S., K., \& Govindarajulu, C. (2006). Technologcal, organizational, and environmental antecedents to web services adoption. Communication of the IIMA, 6(1), 146-158

[23] Marcus, A. (2009). Integrated information systems: A professional field for information designers. Information Design Journal, 17(1), 4-21.

[24] Mayfield, M., Mayfield, J., \& Lunce, S. (2003). Human resource information systems: a review and model development. American Society for Competitiveness, 11(1), 139-151

[25] Mishra, A,. \& Akman, I.(2010). Information technology in human resource management: an empirical assessment. Public Personnel Management, 39(3), 243-262

[26] Nzuve, S., N., M., \& Mwarey, C. (2013). Human Resources Planning in Faith Based Hospitals in Kenya, University of Nairobi. Electronic Copy, http://ssrn.com/abstracts=2223924

[27] Obeidat, B., Y. (2012). The relationship between human resource information system (HRIS) functions and human resource management (HRM) functionalities. Journal of Management Research, 4(4), 192-211. http://dx.doi.org/10.5296/jmr.v4i4.2262

[28] Oliveira, T., \& Martins, M. F. (2011). Literature review of information technology adoption models at firm level. The Electronic Journal Information Systems Evaluation, 14(1), 110-121. Available online at www.ejise.com 


\section{International Advanced Research Journal in Science, Engineering and Technology}

Vol. 8, Issue 4, April 2021

\section{DOI: $10.17148 / I A R J S E T .2021 .8419$}

[29] Petter, S., DeLone, W., \& McLean, E. (2008). Measuring information systems success: models, dimensions, measures, and interrelationships. European Journal of Information Systems, 17, 236-263

[30] Rawash, H.N., \& Saydam, S. (2012). The impact of electronic human resource management on organization's market share: an empirical study on the housing bank for trade and finance in Jordan. International Journal of Business and social Sciences, 3(24), 113-120. Available at from www.ijbssnet.com

[31] Richard, O, C., \& John, N, B. (2001). Strategic human resource management effectiveness and firm performance. International Journal Human Resource Management, 12(2). 299-310

[32] Ruel, H. J. M., \& Bondarouk, T. V. (2009). Electronic human resource management. Challenges in the digital era. The International Journal of Human Resource Management. 20(3), 505-514,doi: 10.1080/09585190802707235

[33] Slavic, A., \& Berber, N. ((2013). The role of information systems in human resource management in Serbia. III International Symposium of Engineering Management and Competitiveness 2013(ECM 2013) June 21-22, 2013,Zrenjanin, Serbia

[34] Tan, C, L., \& Nasurdin, A, M. (2011). Human resource management practices and organizational innovation: Assessing the mediating role of knowledge management effectiveness. The Electronic Journal of Knowledge Management, 9(2), 155-167. Avalaible online at www.ejkm.com, accessed on $12 / 02 / 2015$

[35] The Constitution of Kenya, 2010. Revised Edition 2010, published by the National Council for Law Reporting with the Authority of the Attorney General, Nairobi, Kenya

[36] Thong,J.Y.L.(1999). An integrated model of information system adoption in small businesses. Journal of Management Information Systems, 15(4), 187-214. Available at http://ssrn.com/abstract=1977980

[37] Tripathi, K. P. (2011). A Study of Information Systems in Human Resource Management.

An Internal Journal of Computer Applications, 22(8), 9-13

[38] Wade, M. \& Hulland, J. (2004). The resource - based view and information systems research: Review, extension, and suggestions for future research. MIS Quarterly, 28(1), 107-142. Available at http://www.jstor.org/stable/25148626

[39] Warui, C., Mukulu, E., \& Karanja, K. (2015). The influence of management participation on the adoption of HRIS in teachers' service commission (TSC) operations in Kenya. International Journal of Academic Research and Social Sciences, 5(2), 46-60. doi:10.6007/IJARBss/v5-i2/1462

[40] Wit, K.D., Heerwegh, D., \& Verhoeven, J.C.(201). Challenges in the basic ICT skills of freshmen between 2005 and 2009: Who's catching and who's still behind? Education and Information Technologies. 17(2), 205-231. available at http://link.springer.com/article/10.1007\%2Fs10639$011-9154-\mathrm{z}$ 
International Advanced Research Journal in Science, Engineering and Technology

Vol. 8, Issue 4, April 2021

DOI: $10.17148 /$ IARJSET.2021.8419

Figure 5.1: Conceptual Framework

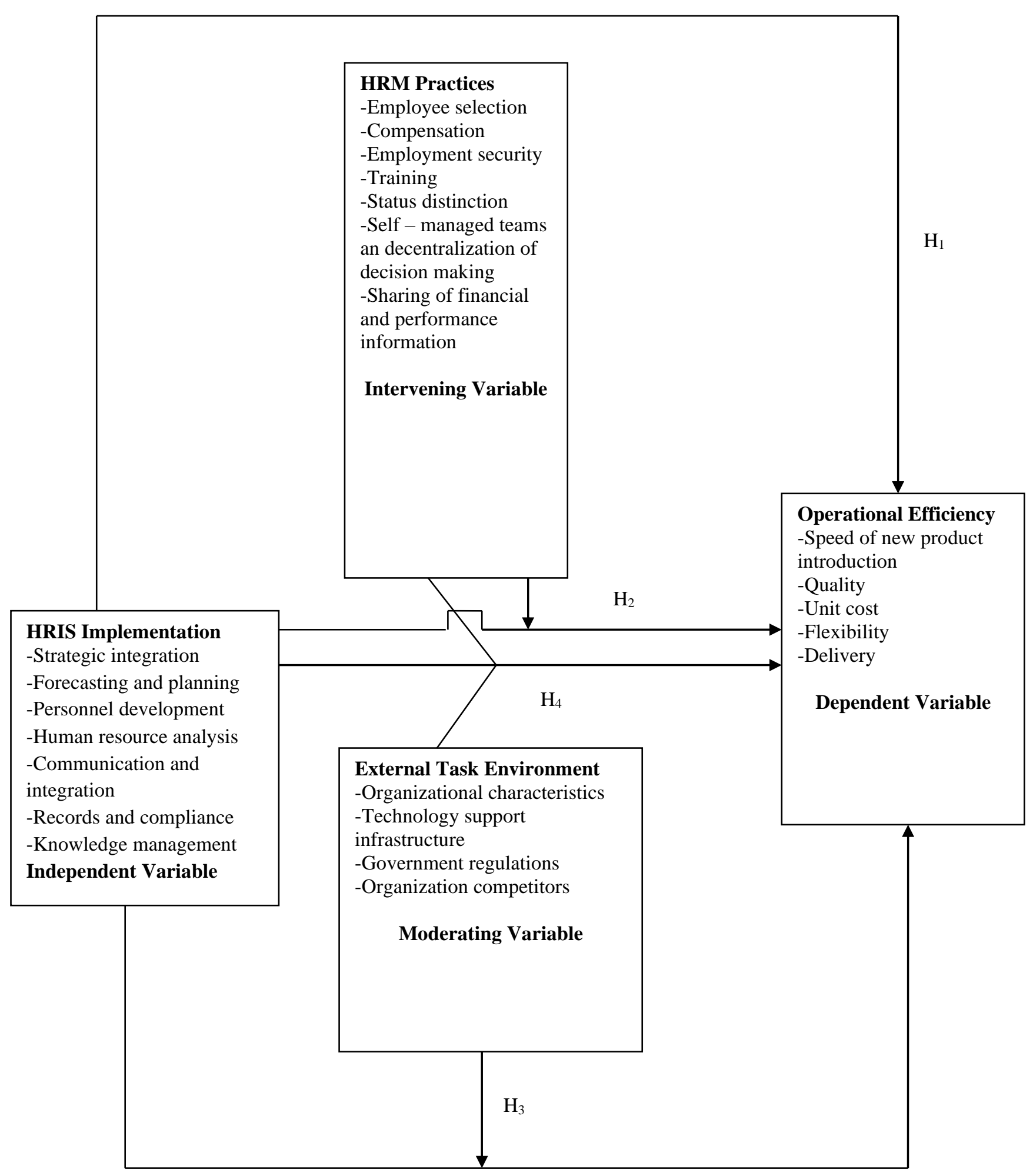

